\title{
Continuous Water-Quality and Suspended-Sediment Transport Monitoring in the San Francisco Bay, California, Water Years 2016-17
}

The U.S. Geological Survey (USGS) monitors water quality and suspended-sediment transport in the San Francisco Bay (Bay) as part of a multi-agency effort to address estuary management, water supply, and ecological concerns. The San Francisco Bay area is home to millions of people, and the Bay teems with plants and both resident and migratory wildlife, and fish. Freshwater mixes with salt water in the Bay and is subject to riverine influences (floods, droughts, managed reservoir releases, and freshwater diversions) and marine influences (tides, waves, and effects of salt water). To understand this environment, the USGS along with its cooperators (see "Acknowledgments"), has been monitoring the Bay's waters continuously since 1988.

Several water-quality characteristics of particular importance to State and Federal resource managers are monitored at key locations throughout the Bay (fig. 1). These water-quality characteristics of interest include salinity, water temperature, and suspended-sediment concentration (SSC). Salinity, which indicates the relative mixing of fresh and ocean waters in the Bay, is derived from specific conductance measurements. Water temperature, along with salinity, affects the density of water, which controls gravity-driven circulation patterns and stratification in the water column. Turbidity, a measure of light scattered from suspended particles in the water, is used to estimate SSC. Suspended sediment affects Bay water quality in multiple ways: it attenuates sunlight in the water column, affecting phytoplankton growth; it can deposit on tidal marsh and intertidal mudflats, which can help restore and sustain these habitats as sea level rises; and it can settle in ports and shipping channels, which can necessitate dredging. In addition, suspended sediment often carries adsorbed contaminants as it is transported in the water column, which affects their distribution and concentration in the environment. Excessive concentrations of sediment-adsorbed contaminants in deposits on the bottom of the Bay can affect ecosystem health.

External factors, such as tidal currents and wind, also can affect water quality in the Bay. Tidal currents in the Bay change direction four times daily, and wind direction and intensity also typically vary on a daily cycle. Consequently, salinity, water temperature, and SSC vary spatially and temporally throughout the Bay. Therefore, continuous measurements in multiple locations are needed to monitor these changes. Data collected at eight stations are transmitted in near real-time using cellular telemetry. This fact sheet provides information about the USGS San Francisco Bay water-quality monitoring network. Internet links to access the resulting continuous water-quality data collected by the USGS also are provided.

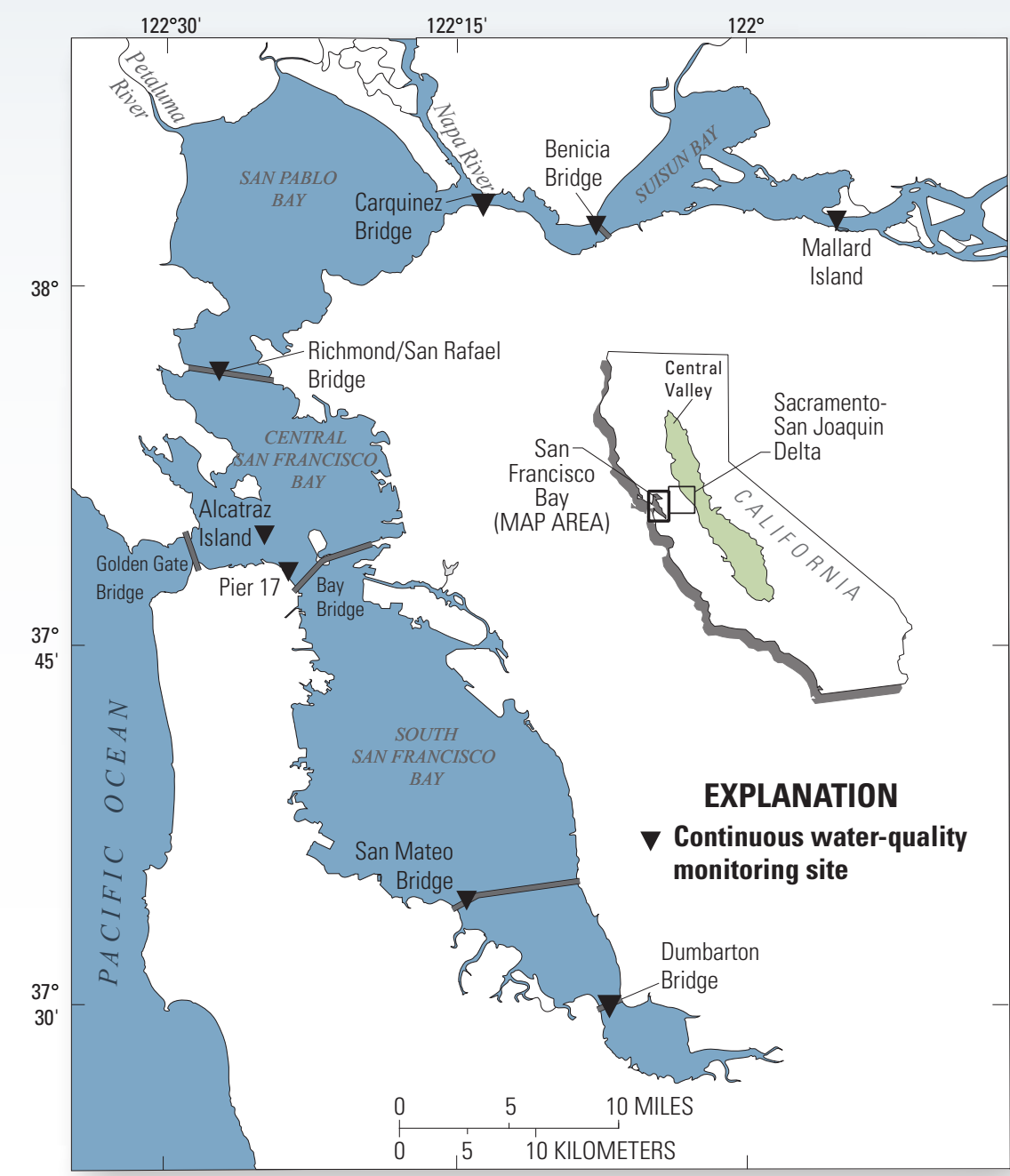

Base modified from U.S. Geological Survey and other Federal and State digital data, various scales;

Albers Equal-Area Conic projection, standard parallels are $29^{\circ} 30^{\prime} \mathrm{N}$. and $45^{\circ} 30^{\prime} \mathrm{N}$.; North American Datum of 1983

Figure 1. San Francisco Bay study area, California. 


\section{Program Overview}

Continuous water-quality measurements are collected at eight stations in the Bay (fig. 1; table 1). Instruments typically are suspended in the water from a stainless-steel cable that is anchored to the bottom (figs. 2, 3) and are equipped with a variety of sensors. Data are recorded every 15 minutes and are transmitted by cellular telemetry (yielding provisional data available within 1 hour of measurement) or retrieved during periodic site visits (yielding provisional data available within 1 week of the site visit). Table 1 lists the vertical location of the instruments at each station and provides the percentage of valid data collected during water years 2016 and 2017. The percentage of valid data ranged from 69 to 99 with an average of 89 across all parameters and stations. The variability in the range of values is attributed to sensor failure and biological fouling. Biological growth (fig. 4) affects sensor readings and usually increases with time, which requires the affected data to be revised or deleted. Every 2-5 weeks, each site is visited to clean and calibrate the instruments and retrieve data as needed. Water samples are collected at the sensor depth to relate the turbidity data to SSC (fig. 5). At some stations, streamflow discharge and cross-sectionally averaged SSC are measured concurrently to estimate the suspendedsediment flux at that location. Streamflow discharge is measured using a boat-mounted acoustic Doppler current profiler (Mueller and others, 2013), and cross-sectionally averaged SSC is determined using water samples collected with isokinetic suspended-sediment samplers (fig. 6; U.S. Geological Survey, 2006) according to established field methods (Edwards and Glysson, 1999). Suspendedsediment flux, in mass per unit time, is computed as the product of the water discharge and the channel-average SSC at the indicated cross section.

Table 1. Continuous water-quality monitoring stations in San Francisco Bay, California, for the period October 1, 2015, through September 30, 2017.

[WY, water year; MLLW, mean lower low water; SSC, suspended-sediment concentration; - , no data; m, meter]

\section{Percent valid data ${ }^{1}$ by water-quality parameter \\ (WY 2016-2017)}

\begin{tabular}{|c|c|c|c|c|c|c|c|}
\hline $\begin{array}{c}\text { Station name and } \\
\text { number }\end{array}$ & $\begin{array}{l}\text { Water depth, } \\
\text { in meters } \\
\text { from MLLW² }\end{array}$ & $\begin{array}{l}\text { Measurement } \\
\text { location }\end{array}$ & $\begin{array}{c}\text { Sensor depth, } \\
\text { in meters from } \\
\text { MLLW }\end{array}$ & $\begin{array}{c}\text { Specific } \\
\text { conductance }\end{array}$ & Temperature & $\begin{array}{l}\text { Turbidity/ } \\
\text { SSC }^{3}\end{array}$ & $\begin{array}{c}\text { Water year } \\
\text { monitoring } \\
\text { began }\end{array}$ \\
\hline \multirow[t]{2}{*}{$\begin{array}{c}\text { Suisun Bay at Mallard } \\
\text { Island } 11185185\end{array}$} & \multirow[t]{2}{*}{7.6} & Upper & $\begin{array}{l}\text { Deployed on a } \\
\text { float } 1 \mathrm{~m} \text { below } \\
\text { water surface }\end{array}$ & - & - & 93 & \multirow[t]{2}{*}{1994} \\
\hline & & Lower & 6.1 & - & - & 75 & \\
\hline \multirow[b]{2}{*}{$\begin{array}{c}\text { Suisun Bay at Benicia } \\
\text { Bridge } 11455780\end{array}$} & \multirow[b]{2}{*}{24.4} & Upper & 2.4 & 98 & 98 & 92 & \multirow[b]{2}{*}{2001} \\
\hline & & Lower & 18.6 & 97 & 97 & 88 & \\
\hline \multirow{2}{*}{$\begin{array}{c}\text { Carquinez Strait at } \\
\text { Carquinez Bridge } \\
11455820\end{array}$} & \multirow[b]{2}{*}{23.8} & Upper & 9.2 & 93 & 96 & - & \multirow[b]{2}{*}{1999} \\
\hline & & Lower & 22.3 & 81 & 81 & - & \\
\hline San Francisco Bay & \multirow[b]{2}{*}{13.7} & Upper & 4.6 & 91 & 93 & 78 & \multirow[b]{2}{*}{2006} \\
\hline $\begin{array}{l}\text { at Richmond/San } \\
\text { Rafael Bridge } \\
375607122264701\end{array}$ & & Lower & 12.2 & 93 & 93 & 75 & \\
\hline $\begin{array}{l}\text { San Francisco Bay } \\
\text { at Alcatraz Island } \\
374938122251801\end{array}$ & 4.9 & Mid-depth & 1.6 & 92 & 99 & 80 & 2003 \\
\hline $\begin{array}{c}\text { San Francisco } \\
\text { Bay at Pier } 17 \\
374811122235001\end{array}$ & 4.9 & Lower & 3.7 & 92 & 93 & 85 & 2013 \\
\hline $\begin{array}{c}\text { San Francisco Bay at } \\
\text { San Mateo Bridge } \\
\text { near Foster City } \\
11162765\end{array}$ & 14.6 & Upper & 11.6 & 97 & 99 & - & 1990 \\
\hline $\begin{array}{c}\text { South San } \\
\text { Francisco Bay at } \\
\text { Dumbarton Bridge } \\
373015122071000\end{array}$ & 13.7 & Upper & 12.5 & 81 & 87 & 69 & 2010 \\
\hline
\end{tabular}

${ }^{1}$ Percentage of valid data represents the number of valid data points for water years 2016 and 2017 divided by the maximum theoretical number of data points $(96$ points per day [35,040 per year] is the maximum number of data points for a 15-minute time series of measurements), multiplied by 100 .

${ }^{2}$ Estimated from the National Oceanic and Atmospheric Administration Nautical Chart Catalog during the 1983-2001 National Tidal Datum Epoch from https://www.charts.noaa.gov/ChartCatalog/MapSelect.html.

${ }^{3}$ Suspended-sediment concentration is calculated from turbidity; therefore, percentage of valid data for turbidity is equal to that for SSC. 


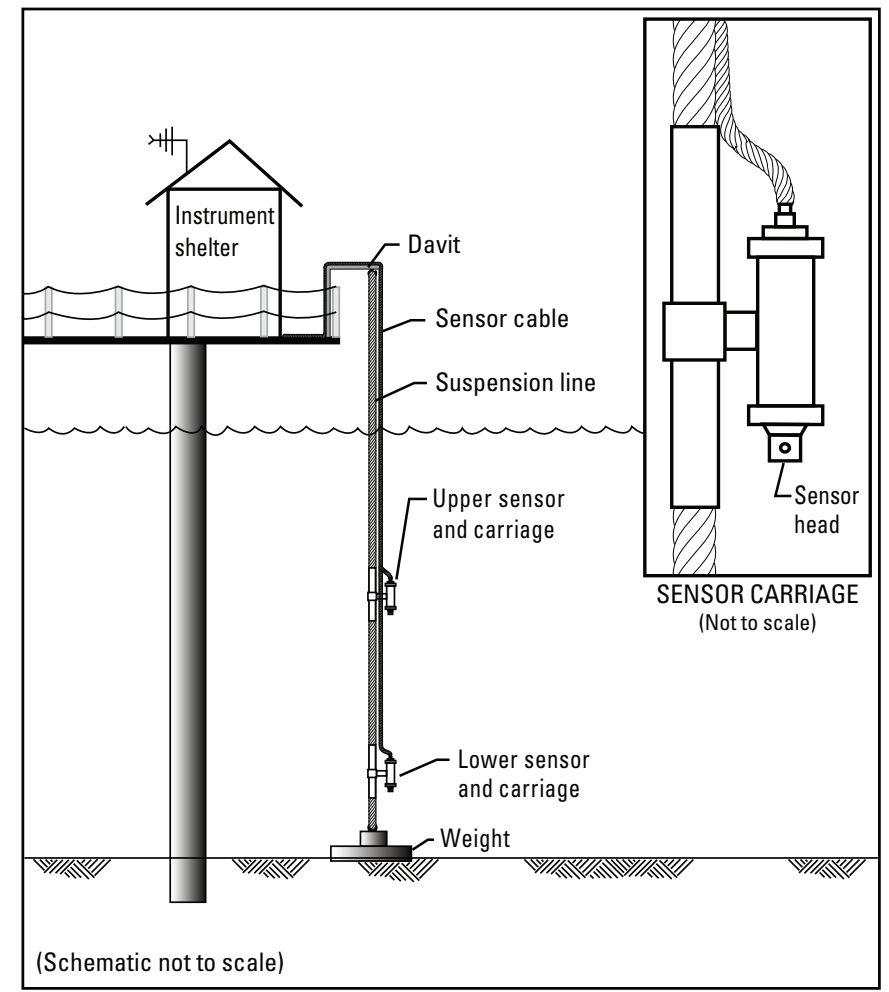

Figure 2. Monitoring installation schematic, San Francisco Bay study.

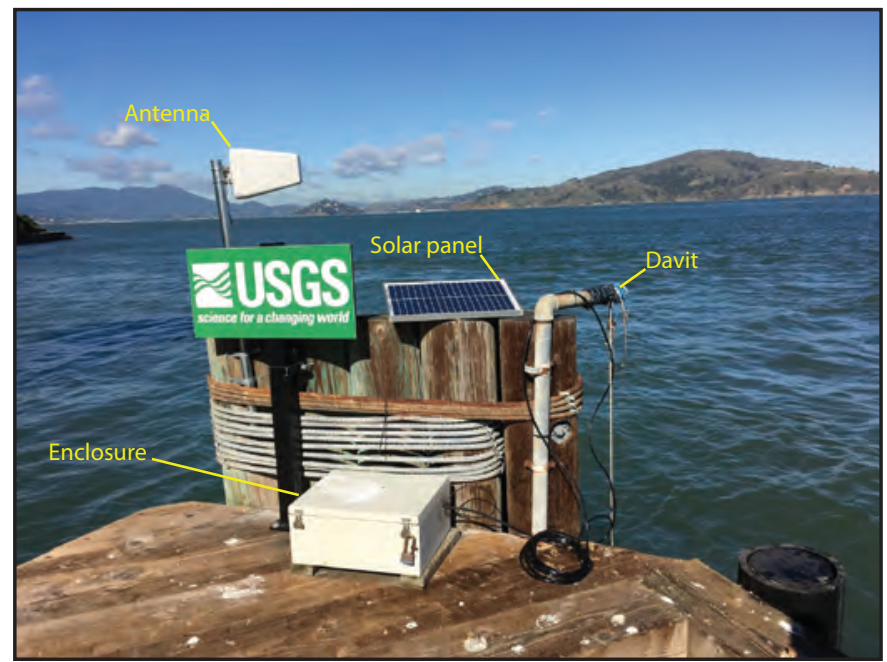

Figure 3. Monitoring installation at Alcatraz Island with labeled equipment. The solar panel provides power to the real-time equipment inside the enclosure. Data are received from the instruments and then transmitted by cellular telemetry. Photograph taken by Darin Einhell.

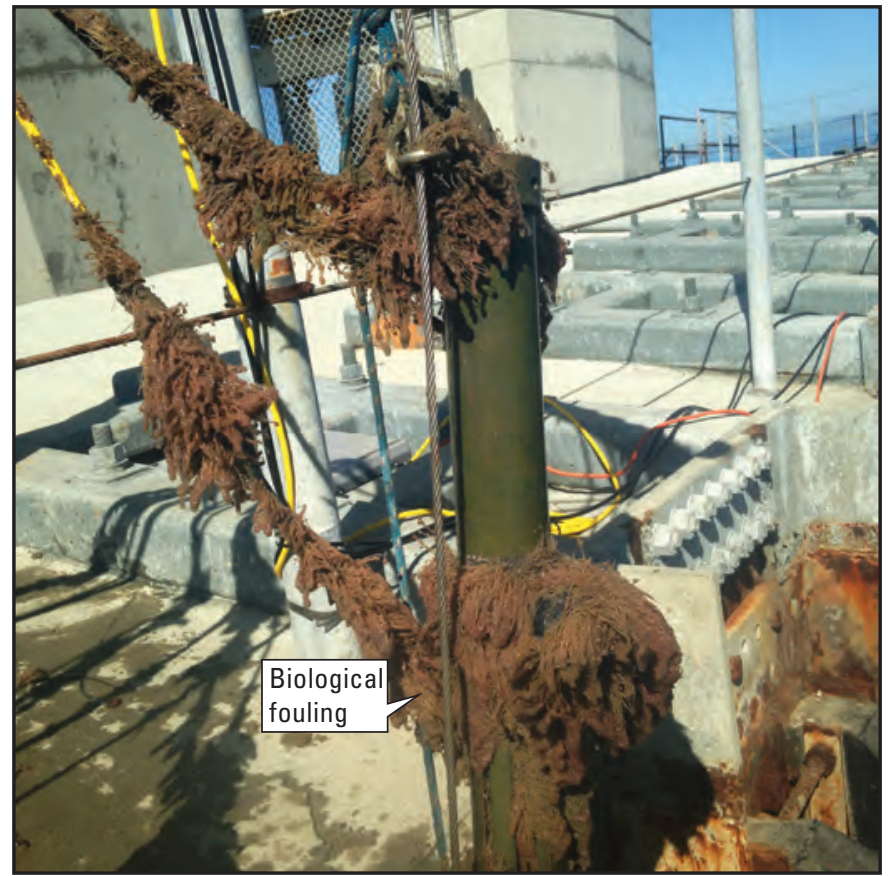

Figure 4. Biological fouling on water-quality instruments at Dumbarton Bridge. Photograph taken by Darin Einhell.

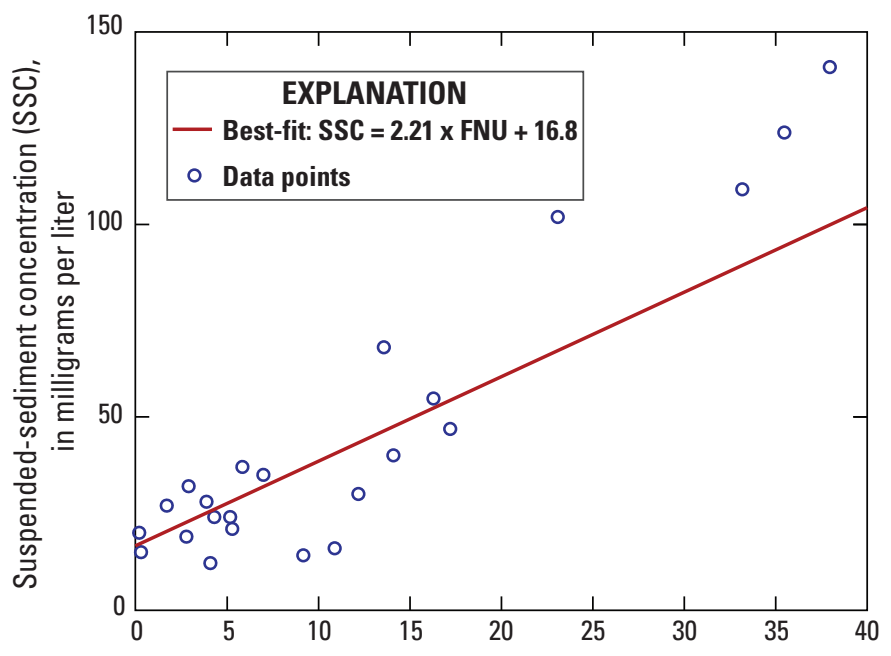

Sensor output, turbidity, in Formazin Nephelometric Units (FNU)

Figure 5. Example rating curve that relates suspended-sediment concentration (SSC) to turbidity using linear regression (from Buchanan and others, 2018). Suspended-sediment concentration measured in discrete water samples is related to optical turbidity sensor output measured continuously to provide a surrogate model to estimate SSC. 


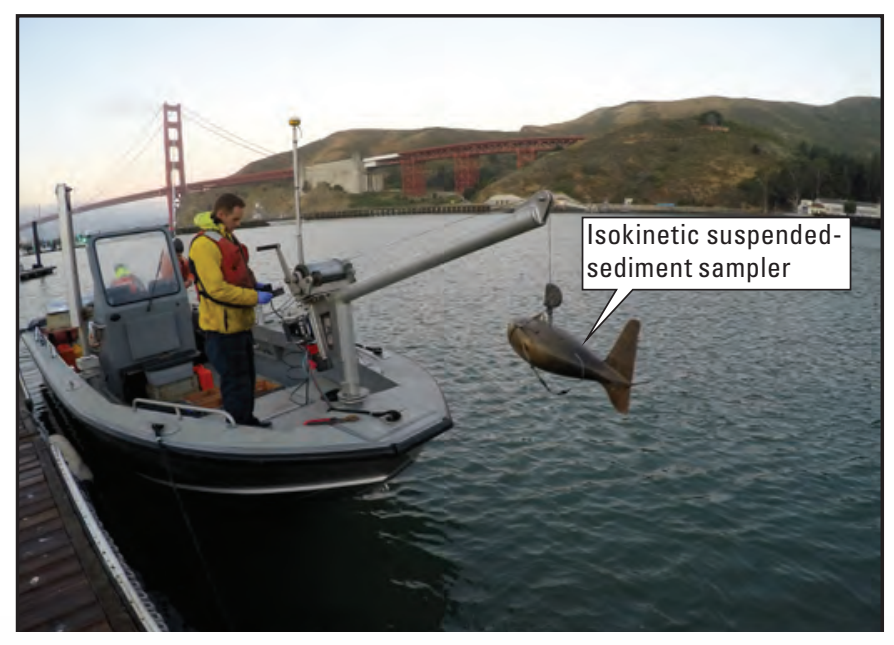

Figure 6. U.S. Geological Survey scientist operating an isokinetic suspended-sediment sampler to collect a water sample at San Francisco Bay near the Golden Gate Bridge. Photograph taken by Paul Work.

Specific-conductance, water-temperature and turbidity data are collected at two depths in the water column at most stations to help characterize the vertical variability. For stations in shallow water (such as Pier 17 and Alcatraz Island), data are collected only at one depth. Specific conductance (reported in microsiemens per centimeter at 25 degrees Celsius) and water temperature (reported in degrees Celsius) are measured using the YSI, Inc., model 6560 conductivity and temperature sensor. ${ }^{1}$ (The use of firm, trade, and brand names in this report is for identification purposes only and does not constitute endorsement by the U.S. Government). Two types of optical sensors are used to measure turbidity: the DTS-12, manufactured by Forest Technology Systems and sensor model 6136, manufactured by YSI, Inc. Data are edited and reviewed before final approval. Data corrections (necessary because of biological fouling or instrument electronic drift) are applied to the affected periods of record following USGS guidelines (Wagner and others, 2006). Further details about these methods are available at https:/ca.water.usgs.gov/projects/baydelta (access the "Methods" section).

Data obtained from this network have several applications, including calibrating numerical models (Bever and MacWilliams, 2013) and understanding the response of Bay water quality to extreme events such as prolonged drought (Downing-Kunz and others, 2015). Continuous water quality and suspendedsediment transport data collected during water years 2016 and 2017 (October 1, 2015, through September 30, 2017) are archived in the USGS National Water Information System and are available to the public at https://waterdata.usgs.gov/nwis.

By Darin C. Einhell, Maureen A. Downing-Kunz, and Daniel N. Livsey

\section{References Cited}

Bever, A.J., and MacWilliams, M.L., 2013, Simulating sediment transport processes in San Pablo Bay using coupled hydrodynamic, wave, and sediment transport models: Marine Geology, v. 345, p. 235-253, https://doi.org/10.1016/ j.margeo.2013.06.012.

Buchanan, P.A., Downing-Kunz, M.A., Schoellhamer, D.H., and Livsey, D.N., 2018, Continuous water-quality and suspendedsediment transport monitoring in the San Francisco Bay, California, water years 2014-15: U.S. Geological Survey Fact Sheet 2018-3013, 5 p., https://doi.org/10.3133/fs20183013.

Downing-Kunz, M.A., Work, P.A., and Shellenbarger, G.G., 2015, Record-high specific conductance and temperature in San Francisco Bay during water year 2014 (ver. 1.1, December 28, 2015): U.S. Geological Survey Open-File Report 2015-1213, 4 p., https://pubs.er.usgs.gov/publication/ ofr20151213.

Edwards, T.K., and Glysson, G.D., 1999, Field methods for measurement of fluvial sediment: U.S. Geological Survey Techniques of Water-Resources Investigations 03-C2, viii, 89 p., https://doi.org/10.3133/twri03C2.

Mueller, D.S., Wagner, C.R., Rehmel, M.S., Oberg, K.A., and Rainville, F., 2013, Measuring discharge with acoustic Doppler current profilers from a moving boat (ver. 2.0, December 2013): U.S. Geological Survey Techniques and Methods, book 3, chap. A22, 95 p., https://doi.org/10.3133/ tm3A22.

U.S. Geological Survey, 2006, Collection of water samples (ver. 2.0): U.S. Geological Survey Techniques of Water-Resources Investigations, book 9, chap. A4, p. 50-58, September 2006, accessed August 24, 2017, at https://doi.org/10.3133/twri09A4.

Wagner, R.J., Boulger, R.W., Jr., Oblinger, C.J., and Smith, B.A., 2006, Guidelines and standard procedures for continuous water-quality monitors - Station operation, record computation, and data reporting: U.S. Geological Survey Techniques and Methods 1-D3, 51 p., https://doi.org/10.3133/tm1D3.

\section{Acknowledgments}

Collection of these data was supported by U.S. Army Corps of Engineers, San Francisco District, as part of the Regional Monitoring and Regional Sediment Management Programs; California Department of Water Resources, as part of the Interagency Ecological Program; California State Coastal Conservancy; Bureau of Reclamation; U.S. Geological Survey Priority Landscapes Program; and U.S. Geological Survey Federal/State Cooperative Program.

\section{For additional information:}

https://ca.water.usgs.gov/projects/baydelta/

California Water Science Center

6000 J Street, Placer Hall, Sacramento, CA 95819

https://ca.water.usgs.gov 